S. M. Timoshenko ${ }^{1}$, orcid.org/0000-0003-4221-9978, M.V. Gubinski ${ }^{2}$, orcid.org/0000-0003-3770-4397, E. M. Niemtsev', orcid.org/0000-0002-2447-3879
1 - Donetsk National Technical University, Pokrovsk, Ukraine, e-mail: stimoshenko155@gmail.com

2 - National Metallurgical Academy of Ukraine, Dnipro, Ukraine

\title{
ENERGY-EFFICIENT SOLUTIONS OF FOUNDRY CLASS STEELMAKING ELECTRIC ARC FURNACE
}

Purpose. Substantiation of solutions aimed at reducing heat losses, mainly, by refractory lining during forced downtime and by steelmaking bath in conditions of traditionally low specific power of transformer.

Methodology. Mathematical modeling of heat and mass transfer processes and numerical experiment.

Findings. A mathematical model of energy-technological processes in arc furnace workspace has been developed to analyze and minimize energy consumption in daily production cycle. Geometrical and operating parameters are taken into account, in particular: variation in arcs energy efficiency at evolution of wells in charge under electrodes during melting process; circulation of melt due to bubbling with inert gas through bottom porous plug; energy loss on heat accumulation by refractory, with cooling water and off-gas.

Originality. For the first time, the concept of increasing energy efficiency of arc furnace has been substantiated, based on the following set of solutions: increase in specific electrical power by reducing of charge at given productivity; reduction of bath shape factor (ratio of diameter to depth) from traditional 5 up to 2.5 by deepening and, accordingly, its radiating surface; optimization of walls and roof cooled surface relative area, where massive heat-absorbing refractory lining is not used; application of energy-saving water-cooled elements with spatial structure that promotes formation of heat-insulating and heat-accumulating slag filling.

Practical value. Implementation of the set of energy-efficient solutions in conditions of typical 6 and 12-t foundry class arc furnaces provides reduction in power consumption and refractory expenditure by $13-15$ and $28-30 \%$ respectively without significant changes in production infrastructure due to reducing energy loss, mainly, for accumulation of heat by refractory lining, and intensification of heat and mass transfer processes in forcibly stirred "deep" bath.

Keywords: electric arc furnace, energy efficiency, “deep” bath, heat and mass transfer, water-cooled elements

Introduction. In foundries electric arc steelmaking furnaces (EAF) are used with a charge, mainly 3-12 t. Energy-intensive classical technology with a low specific transformer power in combination with irregular operation, insufficient opportunities for heat loss utilization and diversification of energy supply, predetermine a low, in comparison with EAF of "large" metallurgy, energy efficiency of foundry class furnaces. In a number of cases, the problem is aggravated by excess capacity due to reorientation of sales markets.

Literature review. As a rule, known mathematical models of heat and mass transfer in EAF describe processes in rhythmically operating furnaces of "large" metallurgy. D. Guo and G. Irons [1] found that $80 \%$ of the arc energy is transmitted by radiation, $15-18 \%$ by thermal conductivity in the bath and $2-5 \%$ is lost in the electrodes. O. Gonzales, M. Ramirez-Argaez and F. Conejo [2] showed that the heating rate of liquid bath increases with arc length. J-C.Gruber, T. Echterhof, H. Pfeifer [3] investigated the effect of high-temperature arc region on the formation of gas flows in EAF workspace, energy losses with the influx of cold air, and evaluated the temperature distribution along radiating surface of the electrodes. M. Kawakami, R. Takatani, L. Brabie [4] generalized the parameters of heat and mass transfer in a forcedly mixed steel bath in the form of criterion equations. J. Li, N. Provatas, G. Irons [5] showed the possibility of intensifying the melting of a continuously loaded charge in a liquid EAF bath.

In mathematical models by V. Logar, D. Dovžan, I. Škrjanc [6]; F. Opitz and P. Treffinger [7]; Yu. A. Stankevich, et al. [8], within the framework of the conjugate problem of heat and mass transfer, solved the system of equations for conservation of mass, momentum and energy in media with moving boundaries and phase transitions; investigated the dynamics of melting the charge and effect of scrap bulk density on it.

Mironov Yu. M. and Petrov V. G. [9] found that in foundry class EAF, the heat loss through casing into environment is significantly higher than in furnaces of "large" metallurgy.

(C) Timoshenko S. M., Gubinski M.V., Niemtsev E. M., 2021
Data on thickness of dynamic, in which there is a predominant change in enthalpy, and the quasi-static thermal layers of the lining were obtained.

Insufficient energy efficiency of the EAF is associated with the notion of technological efficiency of shallow flat bath with a shape factor (ratio of diameter to depth) $m=5.5-4.5$, in contrast with a "deep" bath in converter or ladle furnace unit, having $m \approx 1$. Studies [10] have shown the opportunity in reducing of radiation energy loss in the EAF of "large" metallurgy by $8.5-49 \%$ in different conditions due to decrease in $m$ up to 2.5-1.8. The possibilities of steel refining remain no lower than in a furnace with traditional bath geometry, despite reduction of metal-slag interface, due to intensification of heat and mass transfer processes under conditions of pneumatic mixing in a "deep" bath.

Low specific power of the EAF transformer does not allow the application of traditional for "large" metallurgy watercooled elements (WE) with a dense structure [11] due to technological risks [12], which causes heightened consumption of refractory. A promising solution for given case seems to be WE with a spatial structure, in particular, combined with a lining, which provide heat losses reduced by $25-35 \%$ [13].

In known studies, the issues of combined effect of power input, bath geometry, relative area of WE and traditional lining, and duration of downtime on the foundry class EAF energy efficiency have not been adequately reflected. Therefore, it is of interest to find a rational combination of mentioned factors.

The purpose of the article is to substantiate energy-efficient solutions for foundry class EAF.

Methods. Research methodology is mathematical modeling of technology processes and numerical comparative analysis of energy consumption in EAF daily production cycle. The criterion for effectiveness of considered solutions is the reduction of specific energy losses and relative downtime, refractory savings with minimal changes in the production infrastructure.

Mathematical model. A scheme representing heat and mass transfer processes in the EAF and proposed energy-efficient solutions is shown in Fig. 1. 

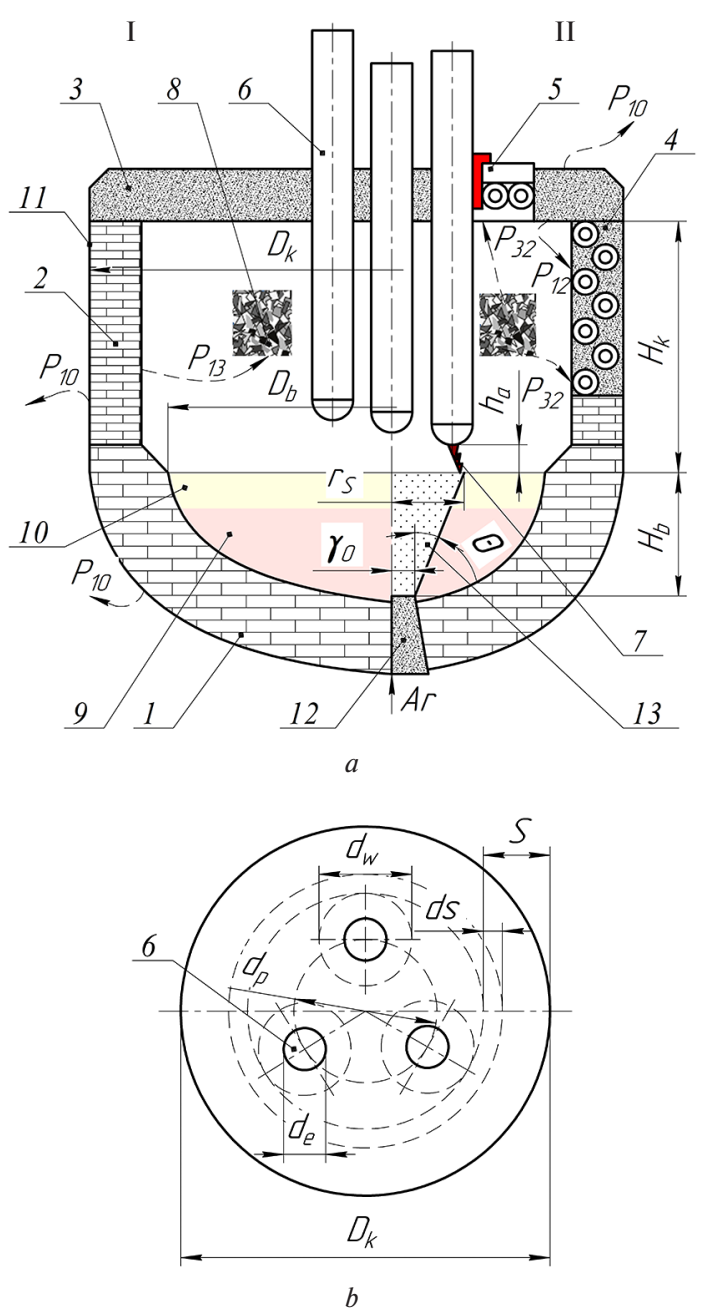

Fig. 1. Base EAF option (I) and energy-efficient solutions (II). Heat and mass transfer in work space (a) and charge melting scheme (b):

1 - bottom; 2 - walls; 3 -roof; 4 - wall WE; 5 - roof WE; 6 electrode; 7 - arc; 8-charge; 9 - steel bath; 10 - slag bath; 11 - casing; 12 - purge unit; 13 - two-phase region. Designations are in the text lows:

The concept of increasing the energy efficiency is as fol-

- growth of specific power input due to a corresponding decrease in the charge at the initial productivity with a decrease in downtime and associated energy losses;

- reduction of the bath shape factor from traditional value $5.5-4.5$ to 2.5 to reduce the radiating surface of the melt;

- installation of a purge unit in the EAF bottom for inert gas (Ar) blowing to intensify heat and mass transfer in the bath;

- applying of WE with a spatial structure instead of a part of walls and roof lining to reduce energy loss on heat accumulation in workspace and consumption of refractory.

Numerical modeling is carried out in Mathcad software package for the classical technology of smelting structural steel in an AC EAF with a cylindrical-spherical bath and a conventionally flat roof. In the roof, the WE is installed in the central area, critical in terms of resistance [13], in the walls - along the perimeter. The relative area of the roof cooled part $\beta_{r}$, evaluated from design considerations, is 0.20 and 0.32 in 6 and $3-\mathrm{t}$ furnaces, respectively. For wall WE, the appropriate parameter $\beta_{w}$ is limited by 0.8 to exclude contact with the melt when the furnace is tilted.

In the thermo-physical representation, steel melting in the EAF includes energy and technological periods with the duration $\tau_{1}$ and $\tau_{2}$. Time of the heat $\tau$ and downtime $\tau^{\prime}$ at daily furnace productivity $G(t)$ and charge $M(t)$, taking into account no-current pauses $\tau_{0}$, is, min

$$
\begin{gathered}
\tau=\tau_{1}+\tau_{2}+\tau_{0} ; \\
\tau^{\prime}=1440-\operatorname{ceil}(G / M) \tau .
\end{gathered}
$$

Heat transfer by radiation. To assess the energy efficiency of the arc during the energy period and the heat loss with water during the technological period, a model of heat exchange by radiation, adapted to the EAF conditions [14], was used. It deals with the primary sources of radiation: the bath surface, arcs and electrodes. The insignificant contribution of secondary radiation caused by dust and gas environment was not taken into account in the comparative analysis. Heat flow power $P_{\text {rad }}$ emitting by surface $F_{\text {rad }}\left(\mathrm{m}^{2}\right)$ with temperature $T_{\text {rad }}(\mathrm{K})$ per unit of receiving surface with temperature $T(\mathrm{~K})$ is, $\mathrm{kW}$

$$
P_{r a d}=\sigma \varepsilon\left(T_{r a d}^{4}-T^{4}\right) \iint_{F_{r a d}}\left(\frac{\cos \theta \cos \gamma}{r^{2}}\right) d F_{r a d},
$$

where $\sigma$ is Stefan-Boltzmann constant, $\mathrm{kW} /\left(\mathrm{m}^{2} \mathrm{~K}^{4}\right)$; $\varepsilon$ is mutual emissivity of heat exchange surfaces; $\theta, \gamma, r$ are direction angles and radius vector, respectively.

The emitting surface of arcs and electrodes in a model is the lateral surface of the cylinders with electrodes pitch diameter $d_{p}$, length $h_{a}$ and $H_{k}-h_{a}$, respectively. The arc length is approximated by the dependence: $h_{a}=0.15+0.003 \mathrm{M}, \mathrm{m}$. The temperature of the bath surface, arc and WE is taken 1820 , 3550 and $1100 \mathrm{~K}$, respectively. Electrode surface temperature $T_{e}=3050+19200 \omega^{4}-48000 \omega^{3}+40400 \omega^{2}-13800 \omega, \mathrm{K}$ is a function of relative height of a point on the conditional cylinder surface above the bath $\omega$, obtained basing on the data [3].

Irretrievable losses associated with radiation in arc furnace without WE are relatively small and occur mainly through the surface of casing. In a furnace with WE, radiation leakage power perceived in the workspace is absorbed mainly by water and amounts to, $\mathrm{kW}$

$$
P_{w e}=k_{w e} \int_{F_{w e}} P_{r a d} d F_{w e},
$$

where $k_{w e}=0.63$ is the averaging coefficient of the heat flux on surface of the WE with a spatial structure covered with a slag [13]; $F_{w e}$ is water-cooled surface, $\mathrm{m}^{2}$.

Calculated value of $P_{w e}$ for the considered group of furnaces is approximated by the multiple regression equation, $\mathrm{kW}$

$$
P_{w e}=50.78 M+46.63 m+833.75 \beta_{w}-282.31 .
$$

Energy period consists in melting of scrap by electric arcs through formation of wells with a diameter $d_{w}=1.35 d_{e}$ [8] under electrodes with diameter $d_{e}$ and expanding them to the EAF walls (Fig. 1, $b$ ).

A feature of small EAF, due to geometry of workspace, is the formation of a common well almost immediately (Fig. 1, $b$ ). The arc energy efficiency ratio in the well $\eta_{w}$, assessed within the model using $(3,4)$, is $0.68-0.70$ [15]. Duration of well formation $\tau_{w}, \mathrm{~s}$ in conditions of uniform active power release in the arcs is determined by the energy balance of melting scrap with a mass $m_{w}=3 \pi \rho_{s}\left(d_{w}^{2} / 4\right)\left(H_{k}+H_{b}\right)$, $\mathrm{t}$

$$
\tau_{w}=\frac{\left[\left(m_{w} k_{s}\left(C_{s}\left(T_{m s}-T_{0}\right)+\gamma_{s}\right)\right]\left(1+k_{g}\right)\right.}{M S \cdot 10^{3} k_{1} \eta_{w} k_{w}},
$$

where $C_{s}, T_{m s}, \gamma_{s}$ are heat capacity, $\mathrm{kJ} /(\mathrm{kg} \mathrm{K})$, melting temperature, $\mathrm{K}$ and fusion heat of scrap, $\mathrm{kJ} / \mathrm{kg}$, respectively; $T_{0}$ is the initial temperature of media, $\mathrm{K} ; k_{s}$ is the scrap consumption factor; $S$ is transformer specific capacity, MVA/t; $k_{1}=$ $=0.80$ is the power factor during scrap melting [11].

Coefficient $k_{g}=0.07$ takes into account heat loss with dust and gas environment, which is formed mainly by the inflow of cold air into the furnace under the action of rarefaction [15]. The parameter $k_{w}=1-\left(\Delta H / H_{k}\right)$ characterizes the reduction of 
radiation shielding by the well walls, when using heavy scrap with bulk density $\rho_{s}>10^{3} \mathrm{~kg} / \mathrm{m}^{3}$ due to decrease in the height of the charge layer by $\Delta H$ relative $H_{k}$, designed for $\rho_{s}=10^{3} \mathrm{~kg} / \mathrm{m}^{3}$. The consequence is an increase in heat loss by radiation and the duration of energy period.

Duration of well expansion $\tau_{w}^{\prime}(s)$ to the EAF walls is evaluated on the basis of energy balance for melting of conventional annular charge layers with a thickness $d s$ and average height $\bar{H}_{k}=H_{k}+0.5 H_{b}$ within the width of the melting space $s$ (Fig. 1, $b$ ), the transfer of heat between which is difficult, due to the high porosity of the charge.

$$
\begin{gathered}
\tau_{w}^{\prime}=\frac{2 \pi \bar{H}_{k} k_{s} \rho_{s}}{P_{1} k_{w}+P_{r}}\left[\left[C_{s}\left(T_{m s}-T_{0}\right) \int_{\frac{d_{p}+d_{w}}{2}}^{\frac{D_{k}}{2}} \frac{s d s}{\eta_{1}}+\right.\right. \\
\left.\left.+\gamma_{s} \int_{\frac{d_{p}+d_{w}}{2}}^{\frac{D_{k}}{2}} \frac{s d s}{\eta_{1}}\right]\left(1+k_{g}\right)+M k_{s l}\left[C_{s l}\left(T_{m s l}-T_{0}\right)+\gamma_{s l}\right]\right],
\end{gathered}
$$

where $\eta_{1}$ is arc energy efficiency during energy period; $C_{s l}$, $T_{m s l}, \gamma_{s l}$ is average heat capacity, $\mathrm{kJ} /(\mathrm{kg} \cdot \mathrm{K})$, temperature, $\mathrm{K}$ and the heat of fusion of slag-forming, $\mathrm{kJ} / \mathrm{kg}$, respectively; $P_{r}$ is thermal power delivered by hot lining, $\mathrm{kW} ; k_{s l 1}=0.035$ is standard slag specific yield in energy period.

In counting $\tau_{w}^{\prime}$ accepted linear dependence of $\eta_{1}$ by coordinate $s$ : from $\eta_{w}$ in the well at $s=0$ to $\eta_{2}$ during the technological period at $s=\left(D_{k}-d_{w}-d_{p}\right) / 2$.

The duration of the energy period includes the stages of formation (6) and expansion (7) of the well, min

$$
\tau_{1}=\left(\tau_{w}+\tau_{w}^{\prime}\right) / 60
$$

Technological period consists in arc heating of the liquid bath to the steel tapping temperature, melting of scrap residues, slag-forming and alloying additives. Arc energy efficiency ratio $\eta_{2}$ determined by active power $P_{2}=M S \cdot 10^{3} k_{2}, \mathrm{~kW}$ (where $k_{2}=0.65-$ power factor during bath heating by arc [11]) and the power of heat loss $P_{\text {loss }}, \mathrm{kW}$

$$
\eta_{2}=\left(P_{2}-P_{\text {loss }}\right) / P_{2} \text {. }
$$

Heat loss power $P_{\text {loss }}=P_{\text {we }}+P_{r}+P_{g}+P_{\text {out }}$ includes components: with cooling water $P_{\text {we }}$ according to (5), for accumulation of heat by refractory lining $P_{r}$, with gases $P_{g}$ and by the surface of the oven to the environment $P_{\text {out }}$. Electrical losses (up to $5-7 \%$ of the input power) are not considered on the condition that the EAF electrical parameters after modernization remain as initial ones.

Value of $P_{r}(\mathrm{~kW})$ is determined by the heat flux through WE-free surface $F_{i n}^{*}=F_{\text {in }}\left[1-\left(\beta_{w}+\beta_{r}\right)\right], \mathrm{m}^{2}$ (where $F_{\text {in }}$ is the inner surface of the workspace, $\left.\mathrm{m}^{2}\right)$ in dynamic lining layer thickness $\delta=0.12 \mathrm{~m}$ and thermal conductivity $\lambda_{r}=2.9 \mathrm{~W} /(\mathrm{m} \cdot \mathrm{K})$ at a temperature difference between working surface and quasistatic layer $\Delta T_{r}=1200 \mathrm{~K}$, according to [9]

$$
P_{r}=\Delta T_{r} \lambda_{r} \cdot 10^{-3} F_{i n}^{*} / \delta .
$$

Factors determining $P_{g}(\mathrm{~kW})$ are the inflow of cold air under the rarefaction in the furnace $\Delta p$, specific oxygen $q_{o x}$ and electrodes $q_{e d}$ consumption. With operating parameters: $\Delta p=$ $=15-20 \mathrm{~Pa}, q_{o x}=12 \mathrm{~nm}^{3} / \mathrm{t}, q_{e d}=9 \mathrm{~kg} / \mathrm{t}$ a regression equation was obtained to estimate $P_{g}$ in furnaces with a charge of 3-12 t, operating according to classical technology

$$
P_{g}=19.41 M+10.50 \text {. }
$$

The value of $P_{\text {out }}(\mathrm{kW})$ is defined by the convective and radiation components of the heat flux from WE-free surfaces $F_{\text {out }}^{*}=F_{\text {out }}\left[1-\left(\beta_{w}+\beta_{r}\right)\right], \mathrm{m}^{2}$ (where $F_{\text {out }}$ is the furnace fence surface, $\mathrm{m}^{2}$ )

$$
P_{\text {out }}=F_{\text {out }}^{*}\left[\alpha_{\text {out }}\left(T_{\text {out }}-T_{0}\right)+\sigma \varepsilon\left(T_{\text {out }}^{4}-T_{0}^{4}\right)\right] .
$$

In the calculation model it is assumed that heat transfer coefficient by convection from the shell $\alpha_{\text {out }}=0.046 \mathrm{~kW} /\left(\mathrm{m}^{2} \cdot \mathrm{K}\right)$ [9], and from bottom and roof is by $30 \%$ lower and higher, respectively; temperature of outer casing surfaces $T_{\text {out }}=470 \mathrm{~K}$; $\varepsilon=1$.

Let us consider regulated operations of the technological period and their duration.

The heating time of bath $\tau_{h}$ (s) from scrap melting point $T_{m s}=1770 \mathrm{~K}$ to tapping temperature $T_{t}=1855 \mathrm{~K}$ is determined by the EAF active power $P_{2} \eta_{2}$ taking into account heat losses (9-12) and alternative chemical energy entering the bath $Q_{2}(\mathrm{~kW})$.

$$
\tau_{h}=\frac{1}{P_{2} \eta_{2}+Q_{2}}\left[\begin{array}{l}
\left(T_{t}-T_{m s}\right)\left(C_{m}+M k_{s l 2} C_{s l}+k_{f} C_{f}\right) \\
+M\left(k_{s l} \gamma_{s l}+k_{f} \gamma_{f}\right)
\end{array}\right],
$$

where $C_{m}, C_{f}$ is heat capacity of liquid steel and ferroalloys, respectively, $\mathrm{kJ} /(\mathrm{kg} \cdot \mathrm{K}) ; \gamma_{f}, k_{f}$ is heat of fusion, $\mathrm{kJ} / \mathrm{kg}$ and consumption factor of ferroalloys, respectively; $k_{s / 2}=0.030$ is standard slag specific yield in technological period.

Assessment of $Q_{2}=68.4 M(\mathrm{~kW})$ was carried out basing on the heat of oxidation reactions of carbon and iron with gaseous oxygen 32.8 and $5.2 \mathrm{MJ} / \mathrm{kg}$ (with the ratio $\mathrm{FeO}$ and $\mathrm{Fe}_{2} \mathrm{O}_{3} 7$ to 3) and the degree of its assimilation by the bath, according to experimental data, 20 and $75 \%$, respectively [11]. At typical $q_{o x}=12 \mathrm{~m}^{3} / \mathrm{t}$, the duration of oxidation period is $30 \mathrm{~min}$. and the regulated amount of oxidized carbon is $6 \mathrm{~kg} / \mathrm{t}$, the remainder of oxygen is consumed mainly for the oxidation of iron in the amount of $20 \mathrm{~kg} / \mathrm{t}$. Insignificant contribution of the heat of other reactions was not taken into account in (13).

Dephosphorization of steel is combined with melting of the charge and does not encounter kinetic difficulties in connection with decrease in bath shape factor during modernization of the furnace [15].

Desulfurization kinetics is defined by the sulfur flow $J_{S}$, $\mathrm{kg} / \mathrm{s}$ caused by metal-slag concentration difference $\Delta[S]$ $\left(\mathrm{kg} / \mathrm{m}^{3}\right)$, mass transfer coefficient $\beta_{S}(\mathrm{~m} / \mathrm{s})$ and metal-slag interface $F_{m s}\left(\mathrm{~m}^{2}\right)$

$$
J_{S}=\beta_{S} F_{m s} \Delta[S] .
$$

Equation (14) assumes definition of $\beta_{S}$ in the steelmaking bath from the criterion equation of mass transfer [4], taking into account different process intensity in active spot area above the purge unit and at the bath periphery [15]. Active spot radius $r_{s}=r_{0}+H_{b} \cdot \operatorname{tg}(\theta)$ (Fig. $1, a$ ) is determined by size of purge unit $r_{0}$, opening angle of two-phase region $\theta$ [16], inert gas flow rate and bath depth. The average flow rate of liquid steel in the two-phase region and at the bath periphery is described by empirical dependences $[16,17]$ on the inert gas flow rate and bath geometry.

The area of the interface in the active spot is total surface of inert gas bubbles in the slag layer, which is determined by the gas content ratio of the two-phase region and average bubble size. Bubbles carry metal droplets into the slag, on the surface films of which the desulfurization reaction takes place, as well as metal-slag interface. At the periphery of the bath, the interface is area of the ring, concentric with the active spot within the bath.

Estimation of desulfurization duration of liquid steel with account its density, sulfur content in scrap and finished metal, respectively $[S]_{s}$ and $[S]_{m}(\%)$ is, $\mathrm{s}$

$$
\tau_{S}=\left([S]_{s}-[S]_{m}\right) 10 M / J_{S} .
$$

Melting time $\tau_{f}$ of a piece of ferroalloy weighing $m_{f}(\mathrm{~kg})$ and surface $F_{f}\left(\mathrm{~m}^{2}\right)$ in a steel bath is described by the SemikinStark equation, $\mathrm{s}$.

$$
\tau_{f}=\frac{\left(m_{f} / S_{f}\right) C_{f}}{\alpha_{m}} \ln \left(\frac{T_{t}-T_{0}}{T_{t}-T_{m f}}\right),
$$


where $C_{f}, T_{m f}$ is heat capacity, $\mathrm{J} /(\mathrm{kg} \cdot \mathrm{K})$ and melting temperature of ferroalloy, $\mathrm{K}$, respectively; $\alpha_{m}$ is heat transfer coefficient in a liquid bath, $\mathrm{W} /\left(\mathrm{m}^{2} \cdot \mathrm{K}\right)$.

Coefficient $\alpha_{m}$ is fond from criterion equation of heat exchange in stirred steelmaking bath [4].

Averaging time of steel by chemical composition and temperature is determined by the empirical dependence [17] on the geometry of the bath $\left(D_{b}, H_{b}, \mathrm{~m}\right)$ and inert gas consumption $Q_{a r}\left(\mathrm{~nm}^{3} / \mathrm{s}\right)$, s

$$
\tau_{\text {mix }}=25.4 Q_{A r}^{-0.33} H_{b}^{-1}\left(D_{b} / 2\right)^{2.33} .
$$

Due to the simultaneous flow of desulfurization, alloying, heating and averaging of the bath, the duration of technological period $\tau_{2}$ is determined by the longest operation. The estimates of procedure time are given in Table 1 for working conditions, mentioned below. The sulfur content in scrap, steel and lime is $0.06,0.025$ and $0.08 \%$, respectively; slag specific yield is 0.035 ; sulfur distribution coefficient between slag and metal is $L_{S}=43$ [16]. Steel is alloyed with ferromanganese ФMH75 based on receiving $2 \% \mathrm{Mn}$ from $0.3 \%$ after melting; assimilation rate of $\mathrm{Mn}$ is 0.8 ; lump size is $5 \times 5 \times 7 \mathrm{~cm}$; density $7140 \mathrm{~kg} / \mathrm{m}^{3}$; melting temperature $1530 \mathrm{~K}$. Inert gas flow rate is $5 \mathrm{~nm}^{3} / \mathrm{h}$; average bubble diameter is $0.01 \mathrm{~m}$; the purge unit diameter is $0.2 \mathrm{~m}$.

Thus, the duration of technological period is determined by desulfurization time

$$
\tau_{2}=\tau_{S}
$$

Furnace downtime. Dynamics of changes in the enthalpy of the EAF workspace, including lining, WE and loaded scrap, during the downtime of the furnace (2) is described by the equation, $\mathrm{kWh} / \mathrm{t}$

$$
H_{a}=\left(\int_{0}^{\tau^{\prime}}\left(d P_{10}+d P_{12}+d P_{13}\right) d \tau^{\prime} / 60\right) / G,
$$

where $P_{10}, P_{12}, P_{13}$ are power loss of energy by the casing, the surface of the lining on WE (not shielded with scrap) and for scrap, respectively, kW (Fig. 1).

Parameter $P_{10}$ has a structure similar to (12). A special feature is the setting of a temporary function for $\alpha_{\text {out }}=31.5 \ln (200-$ $\left.-0.0011 \tau^{\prime}\right)-120.8, \mathrm{~W} /\left(\mathrm{m}^{2} \cdot \mathrm{K}\right)$, in which the expression under the logarithm is an empirical dependence $T_{\text {out }}$ from $\tau^{\prime}$, derived from data [9].

Scrap, heated by the radiation energy of the lining, transfers part $P_{32}$ of the heat to WE, which is taken into account in (19) through current scrap temperature. The expression for residual enthalpy of scrap has a form, $\mathrm{kWh} / \mathrm{t}$

$$
H_{s}=\int_{0}^{\tau^{\prime}}\left(d P_{13}-d P_{32}\right) d \tau^{\prime} / G
$$

In the calculations of heat transfer inside the furnace, only the radiation component was taken into account, and the con-

Table 1

Estimation of the duration of technological period procedures

\begin{tabular}{|l|c|c|c|c|}
\hline \multirow{2}{*}{$\begin{array}{c}\text { Technological operation } \\
\text { (calculation formula) }\end{array}$} & \multicolumn{3}{|c|}{$\begin{array}{c}\text { EAF } \\
\text { base }\end{array}$} & \multicolumn{2}{c|}{$\begin{array}{c}\text { EAF } \\
\text { modernized }\end{array}$} \\
\cline { 2 - 5 } & $12-\mathrm{t}$ & $6-\mathrm{t}$ & $6-\mathrm{t}$ & 3 -t \\
\hline Bath heating (13) & 18.2 & 10.1 & 21.4 & 11.8 \\
\hline Desulfurization (15) & 54.2 & 34.7 & 32.8 & 20.2 \\
\hline Melting of ferroalloys (16) & 13.1 & 6.1 & 5.9 & 2.7 \\
\hline Bath averaging (17) & 12.3 & 3.5 & 9.3 & 2.6 \\
\hline
\end{tabular}

vective component (estimation of its contribution is 2-5\%) was neglected. Expressions for $P_{12}, P_{13}, P_{32}$ are similar in structure to the second term of (12). Radiation heat transfer parameters: mutual emissivity and mutual irradiance factor are taken according to [18]. In calculating the average temperature of the lining, its dynamic layer is considered with a thickness $\delta=$ $=0.12 \mathrm{~m}$ and slag on WE $0.05 \mathrm{~m}$ thick, whose temperature quickly takes on water temperature $T_{0}$.

Energy losses and refractory consumption. When assessing energy losses in the EAF the components $(5,10-12)$, the costs of heat accumulation (19) minus the enthalpy of pre-loaded scrap (20), taking into account the time of its exertion in the daily working cycle, are considered. It is assumed that energy loss with cooling water (5) takes place in the technological (18) and during half of the energy (8) period. The equation for specific energy losses has the form, $\mathrm{kWh} / \mathrm{t}$

$$
Q_{\text {loss }}=\left[\left[\begin{array}{l}
P_{\text {we }}\left(\tau_{2}+0,5 \tau_{1}\right)+ \\
\left(P_{g}+P_{o u t}\right) \tau+P_{r} \tau_{2}
\end{array}\right] / M\right]+\left(H_{a}-H_{s}\right) .
$$

When evaluating refractory consumption, the same lining durability in similar zones was taken for base and modernized furnace. The lining mass in given conditions is determined by the bath geometry (a cylindrical-spherical shape of the bath is adopted with a ratio of elements in height of 1 to 1 ) and the space for placing the charge above it, thickness of the lining zones (bottom, walls, roof) corresponding to typical furnaces of given charge, relative area of WE, density of refractory.

Numerical simulation results. The estimation of average arc energy efficiency coefficient $\eta_{1}$ during energy period of the heat (at $s=s / 2$ ), taking into account the influence of a set of parameters: $m, \beta_{\mathrm{w}}, S$ and $\rho_{S}$, is shown in Figs. 2, $a, b$. Impact of bath shape factor $m$ and specific power $S$ reflected by curves 1,2 for the base $\left(S=0.5 \mathrm{MVA} / \mathrm{t}, \beta_{w}=0, \rho_{S}=1 \mathrm{t} / \mathrm{m}^{3}\right) 12$ and $6-\mathrm{t}$ furnaces, respectively, and curve 3 for 6 -t modernized unit $\left(S=1 \mathrm{MVA} / \mathrm{t}, \beta_{w}=0.6, \rho_{S}=1 \mathrm{t} / \mathrm{m}^{3}\right)$. Effect of walls WE relative area $\beta_{w}$ on $\eta_{1}$ for $3-\mathrm{t}$ modernized furnace is presented by curves 4, 5, 6 corresponding to $\beta_{w}=0.4,0.6$ and 0.8 (Fig. 2, $a$ ).

Ratio of melting time in modernized and base furnaces $\tau_{1}^{*}$, when varying $\beta_{w}$ and $\rho_{S}$, is shown in Fig. 2,c. Curves 7 and 8 refer respectively to 6 and 3 -t modernized furnaces at $\rho_{S}=1$, curve $9-$ to 3 -t unit at $\rho_{S}=1.5 \mathrm{t} / \mathrm{m}^{3}$.

The complex influence of energy and geometry factors on the arc thermal efficiency seems ambiguous, as evidenced by the extreme dependence $\eta_{1}$ versus $m$ (Fig. 2, $a$ ). The result is determined by interrelation of the heat loss values: with cooling water, for heat accumulation by lining and through the casing into environment.

Use of heavy scrap with $\rho_{S}>1 \mathrm{t} / \mathrm{m}^{3}$ negatively affects on the EAF energy efficiency (Fig. 2,c) through reduced opportunity of radiation shielding.

Fig. 3 shows the dependences between arc energy efficiency $\eta_{2}$ during technological period and parameters of the EAF: $S, m, \beta_{w}$. Curves 1,2 refer to the EAF with a base geometry of 12 and $6 \mathrm{t}$, curves $3,4-$ to modernized 6 and $3 \mathrm{t}$ furnaces, respectively. The values, varied in numerical modeling, correspond to the conditions of Fig. 2.

During technological period, with a decrease in bath shape factor, the energy efficiency of arc heating increases (Fig. 3, $b$ ) due to reduction in heat loss by radiation and intensification of heat and mass transfer processes in the "deep" bath (Table 1). Magnification of $\beta_{w}$ under the conditions of open radiating bath leads to decrease in efficiency of arc heating (Fig. 3,c). Reduction of relative energy losses with increasing specific power causes growth of $\eta_{1}$ (Fig. 2,b) and $\eta_{2}$ (Fig. 3, a), which is an argument in favor of the proposed concept of EAF modernization.

The dynamics of changes in the temperature of lining, preloaded scrap and energy losses for heat accumulation in the workspace are presented in Fig. 4. 

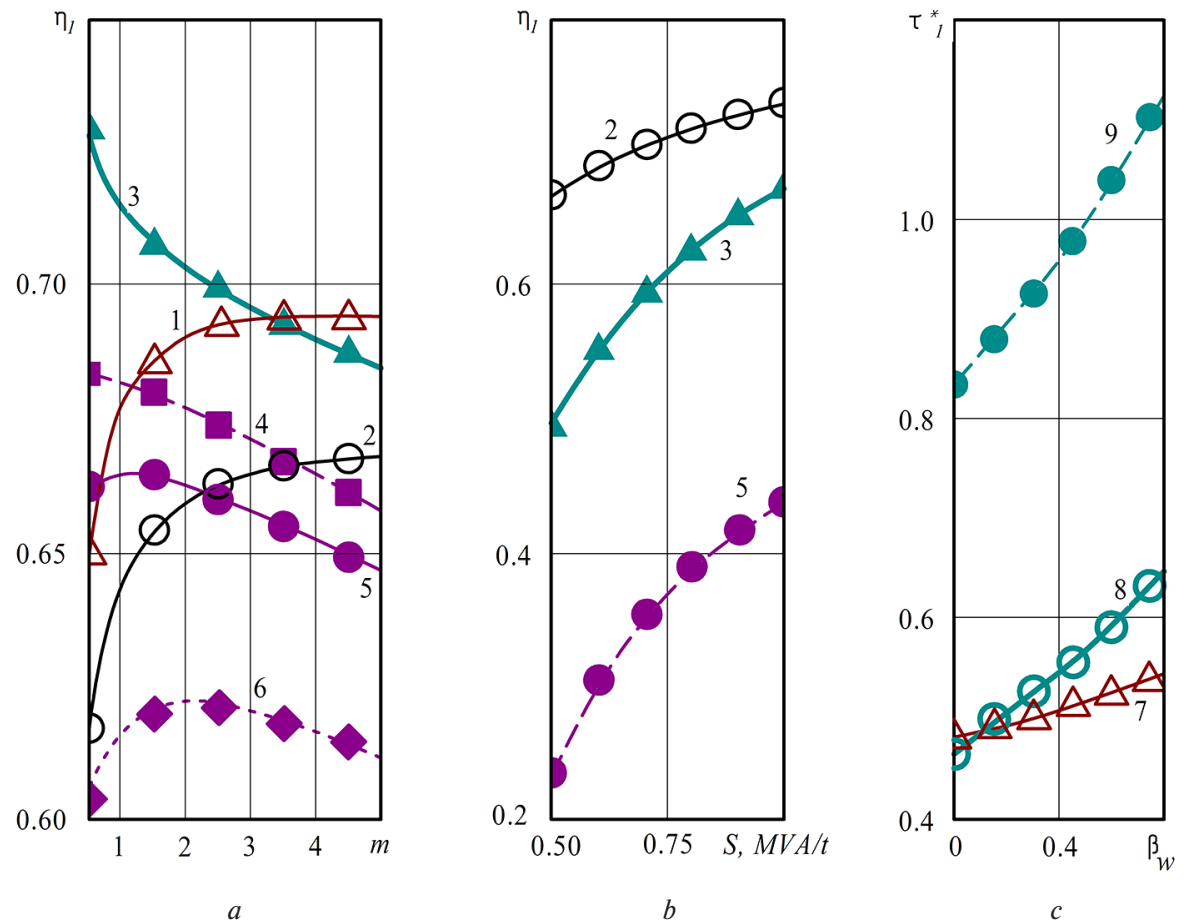

Fig. 2. Arc energy efficiency $\eta_{1}$ during energy period of the heat versus bath shape factor $m(a)$ and specific power input $S(b)$. Relative melting duration $\tau_{1}^{*}$ versus WE of walls relative area $\beta_{w}(c)$. Designations are in the text
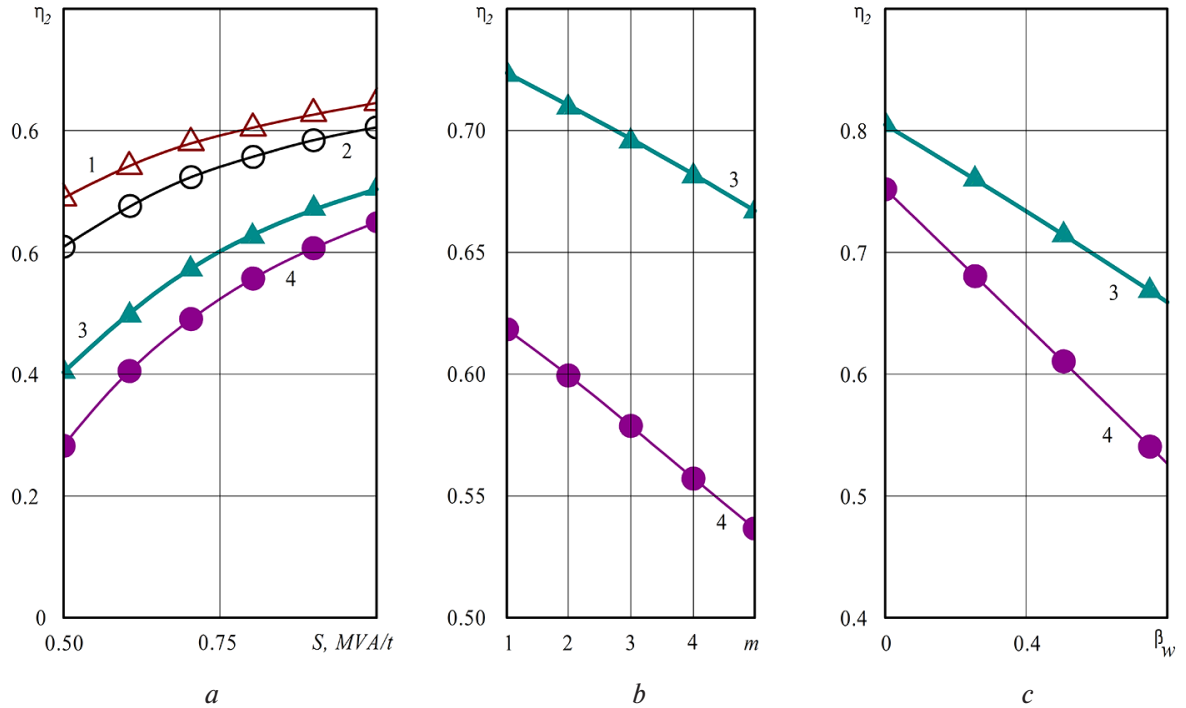

Fig. 3. Arc energy efficiency $\eta_{2}$ in technological period of the heat versus specific power input $S(a)$, bath shape factor $m(b)$ and WE of walls relative area $\beta_{w}(c)$. Designations are in the text

Curve 1 refers to the base 12-t furnace, curves 2,3 - to modernized 6 and 3-t EAF, respectively. Values of parameters varied in numerical simulation $S, m, \beta_{w}$ correspond to the conditions in Figs. 2, 3.

During downtime, the temperature of lining and scrap in upgraded furnace decreases more dynamically (Figs. 4, $a, b$ ), which is due to scale factor of $M$ and growth of $\beta_{w}$. However, less downtime allows saving more heat in the workspace and significantly reducing energy losses for accumulation (Fig. 4,c).

Evaluated thermal and technology parameters for operating values of $G$ in 6 and 12 base furnaces 30 and $60 \mathrm{t} /$ day, taking into account $(1,2,21)$ and $\tau_{0}=20 \mathrm{~min}$, are given in Table 2 .

As a result of the EAF modernization, the energy losses, according to calculation model, are reduced by $13-15 \%$ or by $50-51 \mathrm{kWh} / \mathrm{t}$ and the relative operating time in the daily cycle of the furnace increases from $0.65-0.74$ to $0.82-0.87$.
Relative savings of refractory due to modernization of the EAF, taking into account the restrictions according to conditions of loading the charge in one step, are shown in Fig. 5.

Reduction of the furnaces charge by half and the bath shape factor from 5 to 2.5 , with using WE, provides a possibility of refractory savings by $28-30 \%$.

Conclusion. Based on numerical modeling of heat and mass transfer processes, taking into account the change in the energy efficiency of the arc during the melting process and the workspace thermal state during downtime, the concept of increasing the energy efficiency of foundry class EAF in the conditions of existing infrastructure, has been substantiated. It involves double growth of specific input power with corresponding decrease in the charge at given productivity; reducing the bath shape factor from 5 up to 2.5 and, accordingly, its 

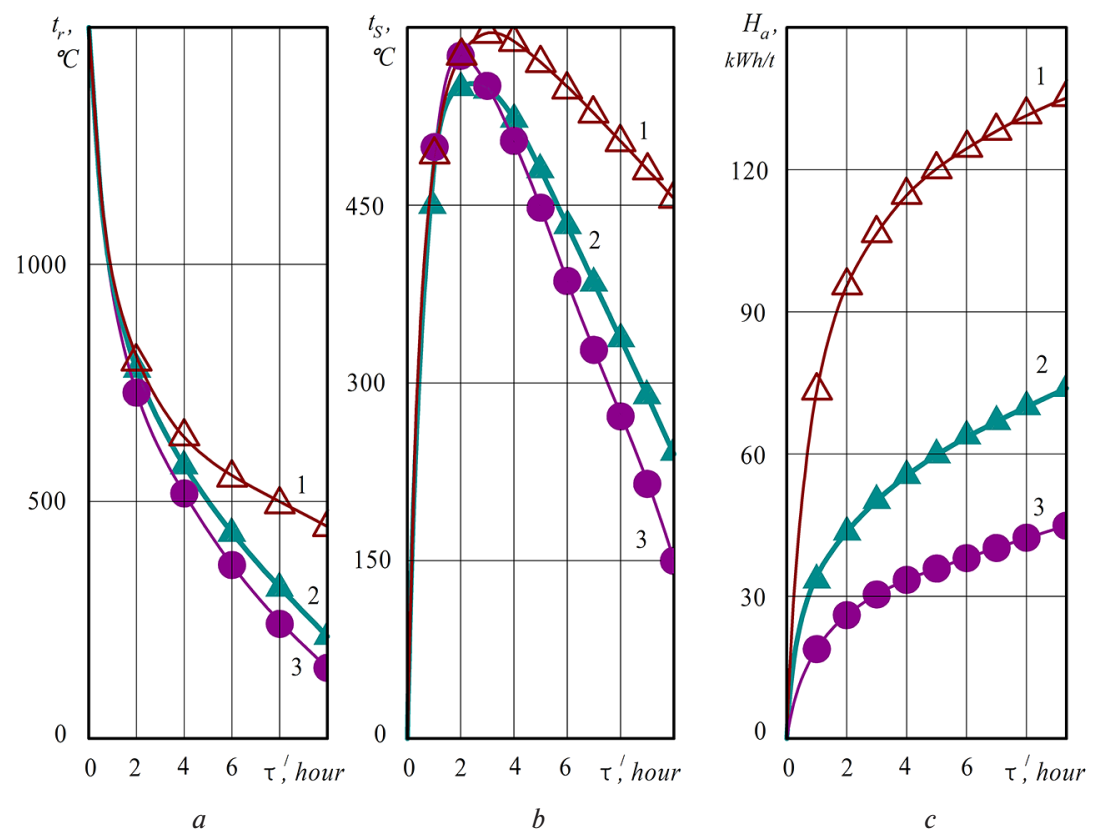

Fig. 4. Lining temperature $t_{r}(a)$, scrap temperature $t_{s}(b)$ and energy losses for heat accumulation $H_{a}(c)$ versus EAF downtime. Designations are in the text

Table 2

Evaluated EAF working parameters

\begin{tabular}{|l|c|c|c|c|}
\hline \multirow{2}{*}{$\begin{array}{l}\text { Characteris- } \\
\text { tic of EAF }\end{array}$} & \multirow{2}{*}{$\begin{array}{c}\text { Furnace } \\
\text { charge, } \mathrm{t}\end{array}$} & \multirow{2}{*}{$\begin{array}{c}\text { Relative daily } \\
\text { operating time }\end{array}$} & \multicolumn{2}{|c|}{ Specific energy losses } \\
\cline { 4 - 5 } & & $\mathrm{kWh} / \mathrm{t}$ & $\begin{array}{c}\text { Relative } \\
\text { units }\end{array}$ \\
\cline { 4 - 5 } Base & 6 & 0.74 & 338 & 1 \\
\hline Modernized & 6 & 0.65 & 395 & 1 \\
\cline { 2 - 5 } & 3 & 0.87 & 288 & 0.87 \\
\hline
\end{tabular}

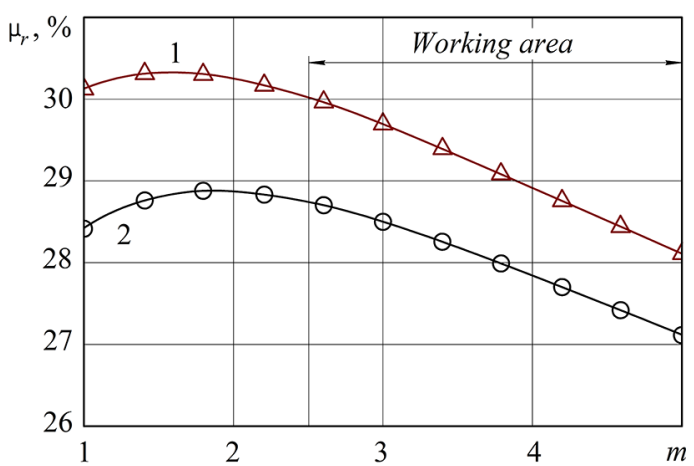

Fig. 5. Refractory savings $\mu_{r}$ for 12-t (curve 1) and 6-t (curve 2) EAF versus bath shape factor $m$ at $W E$ of walls relative area $\beta_{w}=0.6$

radiating surface; optimal combination of water cooled and refractory parts of walls and roof, applying of energy-saving WE with a spatial structure.

For typical 12 and 6-t EAF, a decrease in energy loss for heat accumulation in the workspace, intensification of heat and mass transfer processes in a "deep" bath and local replacement of refractory lining with WE prevail over the growth in energy loss by radiation during the technological period, which leads to energy and refractory savings by $13-15$ and $28-30 \%$, respectively.

\section{References.}

1. Guo, D., \& Irons, J. (2003). Modeling of radiation intensity in an EAF. Third International Conference of CRD in the Minerals and process industry, (pp. 223-228). CSIRO, Melbourne, Australia.

2. Gonsalez, O., Ramirez-Argaez, M., \& Conejo, A. (2010). Effect of arc length on fluid flow and mixing phenomena in electric arc furnace. ISIJ International, 50(1), 1-8.

3. Gruber, J-C., Echterhof, T., \& Pfeifer, H. (2016). Investigation on the Influence of the Arc Region on Heat and Mass Transport in an EAF Freeboard using Numerical Modeling. Steel research international, 87(1), 15-28. https://doi.org/10.1002/srin.201400513.

4. Kawakami, M., Takatani, R., \& Brabie, L. (1999). Heat and mass transfer analysis of scrap melting in steel bath. Tetsu to Hagane, 85(9), 658-665.

5. Li, J., Provatas, N., \& Irons, G. (2008). Modeling of scrap melting in the heel of an EAF. Iron \& Steel Technology, 5(3), 216-223.

6. Logar, V., Dovžan, D., \& Škrjanc, I. (2012). Modeling and validation of an electric arc furnace. ISIJ International, 52(3), 402-423.

7. Opitz, F., \& Treffinger, P. (2016). Physics-based modeling of electric operation, heat transfer, and scrap melting in an AC electric arc furnace. Metallurgical and Material Transactions, 47, 1489-1503. https://doi.org/10.1007/s11663-015-0573-X.

8. Stankevich, Yu., Timoshpol'skii, V., Pavlyukevich, N., German, M., \& Grinchuk, P. (2009). Mathematical modeling of the heating and melting of the metal charge in an electric arc furnace. Journal of Engineering Physics and Thermophysics, 82(2), 221-235.

9. Mironov, Yu. M., \& Petrov, V. G. (2010). Thermal losses and power efficiency of arc steelmaking furnaces. Metally (Russian Metallurgy), $12,1141-1144$.

10. Timoshenko, S., Stovpchenko, A., Kostetski, Yu., \& Gubinski, M. (2018). Energy efficient solutions for EAF steelmaking. Journal of Achievements in Materials and Manufacturing Engineering, 88(1), 18-24. 11.Toulouevski, Yu., \& Zinurov, I. (2010) Innovation in Electric Arc Furnaces. Scientific Basis for Selection. Berlin (Germany): Springer-Verlag. 12. Biswas, S., Peaslee, K., \& Lekakh, S. (2012). Melting energy efficiency in steel foundries. AFS Transactions 2012 American Foundry Society, Schaumburg, Il. USA, 449-456.

13. Timoshenko, S. M., Doroshenko, A. V., Dyadkov, B. P., Tischenko, P. I., \& Onischenko, S. P. (2018). Energy-efficient solutions for the modernization of low-tonnage arc furnaces of foundry class. Metall $i$ lyt'e Ukrayny (Metal and casting of Ukraine), (3-4), 34-40.

14. Timoshenko, S. N. (2016). Computer modeling bath geometry to improve energy efficiency of electric arc furnace. System Technologies. Regional interuniversity collection of scientific works, 3, 33-39.

15. Timoshenko, S. M., \& Gubinski, M. V. (2019). Deep bath - a way to intensification of heat and mass transfer processes and increase of energy efficiency of the arc steelmaking furnace. Metall i lyt'e Ukrayny (Metal and casting of Ukraine), (10-12), 8-17. 
16. Ghosh, A. (2000). Secondary Steelmaking. Principles and Applications. CRC Press. ISBN 9780849302640

17. Mazumdar, D., \& Guthrie, R.I. (2010). Modeling Energy Dissipation in Slag-Covered Steel Baths in Steelmaking Ladles. Metallurgical and Materials Transactions B, 41, 976-989.

18. Howell, J., Pinar Mengüç, M., \& Siegel, R. (2016). Thermal Radiation Heat Transfer. CRC Press. Taylor \& Francis Group LLC. ISBN-13: 978-1466593268. ISBN-10: 1466593261.

\section{Енергоефективні рішення дугової сталеплавильної печі ливарного класу}

\author{
С. М. Тімошенко ${ }^{1}$, М. В. Губинський ${ }^{2}$, Е. М. Нємцев ${ }^{1}$
}

1 - Донецький національний технічний університет, м. Покровськ, Україна, e-mail: stimoshenko155@gmail.com 2 - Національна металургійна академія України, м. Дніпро, Україна

Мета. Обгрунтування рішень, спрямованих на зниження втрат теплоти, головним чином, футеровкою при вимушених простоях печі і сталеплавильною ванною в умовах традиційно низької питомої потужності трансформатора.

Методика. Математичне моделювання процесів тепломасообміну та чисельний експеримент.

Результати. Розроблена математична модель енерготехнологічних процесів у робочому просторі дугової печі для аналізу й мінімізації енергоспоживання в добовому виробничому циклі. Ураховуються геометричні й режимні параметри, зокрема: енергоефективність дуги при еволюції колодязів під електродами у процесі плавлення шихти; циркуляція розплаву при барботажі ванни інертним газом, що вводиться через донну пористу пробку; втрати енергії на акумуляцію теплоти футеровкою, з охолоджувальною водою та з пилогазовим середовищем.

Наукова новизна. Уперше обгрунтована концепція підвищення енергоефективності дугової печі, заснована на наступному комплексі рішень: збільшення питомої введеної потужності за рахунок зниження садки при даній продуктивності; зменшення коефіцієнта форми ванни (відношення діаметра до глибини) з традиційного 5 до 2,5 і, відповідно, ії̈ поверхні, що випромінює, шляхом поглиблення; оптимізація відносної площі охолоджуваної поверхні стін і зводу, де не використовується масивна теплоємна футеровка; застосування енергозберігаючих водоохолоджуваних елементів із просторовою структурою, що сприяє утворенню теплоізолюючого й теплоакумулюючого гарнісажу.

Практична значимість. Реалізація комплексу енергоефективних рішень в умовах 6 й 12-т типових електродугових печей ливарного класу забезпечує зниження витрати електроенергії та споживання вогнетривів на 13-15 і 28-30\% відповідно, без істотної зміни інфраструктури виробництва за рахунок скорочення втрат енергії, головним чином, на акумуляцію теплоти футеровкою, та інтенсифікації процесів тепломасообміну у примусово перемішуємій «глибокій» ванні.

Ключові слова: електродугова піч, енергоефективність, «глибока» ванна, тепломасоперенос, водоохолоджувані елементи

Recommended for publication by Yu.S. Proidak, Doctor of Technical Sciences. The manuscript was submitted 20.12.20. 